\title{
TITLE:
}

\section{Charles Tomlinson in the "Golfo dei Poeti}

\section{$\operatorname{AUTHOR}(S)$ :}

Robinson, Peter

\section{CITATION:}

Robinson, Peter. Charles Tomlinson in the "Golfo dei Poeti. 英文学評論 1989, 58: [1]-23

ISSUE DATE:

1989-11

URL:

https://doi.org/10.14989/RevEL_58_(1)

RIGHT: 


\title{
Charles Tomlinson in the 'Golfo dei Poeti'
}

\author{
Peter Robinson
}

I

Charles Tomlinson first went to Italy in the autumn of 1951. He had gone there as a secretary to Percy Lubbock, the author of The Craft of Fiction. Lubbock lived in a villa between Lerici and Fiascherino. It is a literary place, with many poetic associations. Across the bay from Lerici, at Portovenere, is Byron's Grotto. Shelley lived in a villa at San Terenzo, up the coast towards La Spezia. D. H. Lawrence was staying in Fiascherino in 1914, reading I Poeti Futuristi (1912). ${ }^{1)}$ Travel northward up the Ligurian coast and there is Monterosso, where you can walk along the Lungomare Eugenio Montale, and further towards Genoa, is Rapallo, where Yeats and Pound had homes. Go southward down the coast to Bocca di Magra: there Vittorio Sereni's family have a holiday house, and Franco Fortini spends his summers. Inland is Sarzana, the town where Guido Cavalcanti was exiled from Florence, where he was thought to have written the ballata whose opening, 'Perch' $i$ ' no spero di tornar giammai', ${ }^{2}$ might be rendered in English as 'Because I do not hope to turn again'. ${ }^{3)}$

Tomlinson had not been at Lubbock's villa Gli scafarit) for a month when he was sacked because of his accent. The incident, and its explanation, are given in the memoir Some Americans. Percy Lubbock-

had been legislating on the pronunciation of the English $a$ as in past and castle, insisting that it should be long also in ants. Clearly he had not revisited the island for a long time, for even the English aristocracy would hesitate to lengthen the $a$ of ants. But what he was evidently indicating - as far, that is, as good manners permitted-was that our Midland $a$ 's sounded displeasing to him. But what of that? One could hardly feel wounded by a man who imagined ants should be pro- 
nounced aunts.

Two weeks later I received my dismissal. It was most mysterious. Lubbock had returned to Florence with Lady Dick-Lauder. The letter came from his step daughter, Iris Origo; he no longer wanted a secrentary. Could one be dismissed for an accent? It hardly seemed plausible, but we could imagine no other cause for offence. ${ }^{5)}$

Tomlinson, however, may have received a lasting wound from this episode, and at an early stage in his life as an artist. He was twenty-four, having been born at Stoke-on-Trent in 1927. The English class system is complex, involving infinitessimal degrees of definition by contrast and comparison. In an interview honouring his sixtieth year, Tomlinson answered the question 'Did you feel your education drew you away from your home background?' with these remarks:

My parents believed in education and so what successes I had were a pleasure to them. We must have been a more sensible lot in Stoke than that lot up in Leeds, to judge from the way the poet Tony Harrison writes. We were virtually all working-class children-I hardly knew what the middle classes were till I got to Cambridge-and no teacher ever tried, as in Harrison's case, to change my accentand this was a grammar school, mind you, nothing experimental about it. Also, you'd never have used a term like 'working class' to describe yourself. You might have spoken of working people or ordinary people. Working class is one of those labels dear to the theoretical and it covers up immense differences. I notice that Harrison's father had a telephone and used to spit in the fire. My father never rose to the first and he'd never have descended to the second. ${ }^{\text {b) }}$

It is one thing to be at ease with your origins when you are a sixty-year-old who has made his literary mark, another when a struggling and winded twentyfour. A wound delivered by Lubbock's dismissal may have been the more painful because of the family pride in Tomlinson's account of his father's possessions and habits. The poet is saying that he comes from good, respectable people. The wounding memory lasted long enough to show in a poem called 'Class', about the Midland pronunciation of the first letter of the alphabet. In 'Class' Tomlinson says that he tried to pronounce the $a h$ of proper English, but couldn't, and the short, hard, regional $a$ 'too visibly shredded his [Lubbock's] fineness' (249). The poem is more openly dismissive of his onetime employer 
than the memoir, though its image of the dead Lubbock being mummified for transportation back to England has a touch of revenge about it.7) Tomlinson-

always thought him an ass

which he pronounced arse.

With the exception of one sentence, 'Class' is written in the first person. Referring to the title of Lubbock's The Craft of Fiction with its tricky-to-pronounce second word, Tomlinson introduces a sense of 'class' meaning 'quality' (also socially complex and ambiguous, given its application to people or to works of art, or the assumption that the one meaning might or should inform the other). He writes: 'that title was full of class' and goes on:

You had only to open your mouth on it to show where you were born and where you belonged.

Tomlinson's lineation divides the statements linked by 'and' to suggest that you don't necessarily and permanently belong where you happened to be born. If you don't remain there, but retain some of your native characteristics-your accent, for example-then your identity may be partially defined by ambiguous relations between places, class positions and the sounds of your own voices. Many English people's speech is unstable in this way.

These changes of place, these fluctuating pronunciations, are cases of translation. Donald Davie's poem 'Housekeeping' has a fine stanza in which the verb appears:

From homestead Autumns in the vale of Chard Translated in youth past any hope of returning, She toiled, my father a baby, through the hard Fellside winters, to Barnsley, soused in the Dearne. ${ }^{8\}}$

Davie is doing some translating himself here: 'Autumns', with its capital letter, and 'winters' without, indicates that the poet's grandmother has moved bet- 
ween literary eras as well as English landscapes. She has been translated from a Golden rural past into the nineteenth-century industrial north. When the poet writes 'She toiled', deferring the indirect object 'to Barnsley' for a line and a half, he effects such a translation: the simple past 'toiled' means 'worked' and begins its life in the poem as a conventional Augustan loco-descriptive term used without an object to describe field-labourers. When it gains the indirect object and northern place name, it means 'walked with effort', and, reinforced by the mention of a baby, pictures a vagrant displaced mother as from a Wordsworth encounter poem. Davie's grandmother is 'Translated in youth' from one literary period into another, from one age to another. She is defined in the poem by where she has come from and where she has got to at one and the same time. The participle 'Translated', meaning 'moved from one place to another', has an Augustan tang about its etymological literalness.

Tomlinson, in the frst of his Clark Lectures, discusses Dryden's use of 'translated' as a synonym for 'metamorphosed' in his version of Ovid's Metamorphosis, Book XV. Tomlinson is commenting on how 'All Things are alter'd' and 'Translated grow, have Sence, or can Discourse'. He notes:

The audacity, the sprezzatura, with which Dryden throws in the word 'Translated' here--he who translated Chaucer into modern English and who said he expected someone to do the same for him one day-wittily incorporates the notion of literary translation into the conception of an ongoing world empowered by the metamorphoses of its own elements $[\ldots]^{9)}$

Tomlinson cites another instance of the word's use in the Ceyx and Alcyone story: 'The Gods their Shapes to Winter-Birds translate'. ${ }^{10)}$ In the second lecture, he extends his ideas of metamorphosis to include 'a sense of the provisional nature of personality', ${ }^{11}$ and translation too can concern itself with the provisional nature of personality. It can focus on what changes and what abides, for as Eliot wrote in 'The Dry Salvages': 'People change, and smile: but the agony abides. '12) Charles Tomlinson's poetry itself explores the overlayerings in a life of changes of place, of social mobility, stylistic development, and human identity-all of which are themselves influenced by and achieved 
through the poet's commitment to foreign cultures and the activity of literary translation.

\section{II}

Relations between accent and identity involve, among many things, the use of pronouns. Imagine the three lines from 'Class' translated into the first person singular: "I had only to open my mouth on it to show where I was born and where I belonged". Having these lines in the second person (and they are the only part of the poem that is) allows a general point to be made: it would be the same for anyone pronouncing The Craft of Fiction. The lines can also sound self-addressed, the poet using 'you' to talk about himself indeterminately. Another poem, 'Tramontana at Lerici', written in the same decade as the Lubbock incident, begins in the second person:

Today, should you let fall a glass it would

Disintegrate, played off with such keenness

Against the cold's resonance (the sounds

Hard, separate and distinct, dropping away

In a diminishing cadence) that you might swear

This was the imitation of glass falling.

This 'you', with 'should' and 'might' rendering conditional its relation to active verbs, effects a concatenation of experiences which anyone might conceivably have. The imagined experience of 'sounds/ Hard, separate and distinct', which forms part of a poetic idea in development, is elaborated around the simple likelihood that "if I drop a glass... I will swear." The poem's opening stan$z$ a places its reader in the midst of sensory events and at a remove from experiences like breaking glasses and swearing, faux pas at a dinner party given by Percy Lubbock. In the third stanza the poem introduces a perceiver to which sensations are attached: 
At evening, one is alarmed by such definition

In as many lost greens as one will give glances to recover, As many again which the landscape

Absorbing into the steady dusk, condenses

From aquamarine to that slow indigo-pitch

Where the light and twilight abandon themselves.

'At evening, one is alarmed': this sounds rather posh. The impersonal pronoun, which can be used as a first person pronoun with an intent to exclude others not hearable in 'you' when it indicates a first person, this 'one' cannot easily express warmth between people. 'Tramontana at Lerici' moves into its final stanza with a distinct drop in temperature:

And the chill grows. In this air

Unfit for politicians and romantics

Dark hardens from blue, effacing the windows:

A tangible block, it will be no accessory

To that which does not concern it. One is ignored

By so much cold suspended in so much night.

In the final lines, the pronoun's social tone and the wind's effects (the 'Tramontana' is a wind) appear to be working in concert to exclude the perceiver: 'One is ignored'. Yet to think of wind and pronoun as acting concertedly would be to miss the presence of a voice saying the poem. This voice is the sign of a body's presence but also of a self's, the body defined as having identity, and of that self in the pronoun 'one' turning itself away from the threshold of its own self. The disembodied voice is a ventriloquism of a class accent delivering a body blow to the poet.

The poem performs the combined coldnesses from which its speaker suffers. Yet this performance has had its influence on how Tomlinson has been received. Michael Schmidt summed this up in his review of the Collected Poems: "The case against the poems is quite simply that they are cold. '13) This is to say that not only is 'one' ignored by 'so much cold', but so are reviewers and readers, who, in turn, have the poet ignored a third time round: in ex- 
perience, in the composition, and in its reception. Kenneth Allott admitted to feeling put off by the fineness of 'Tramontana at Lerici' when anthologising the poem in 1962 . Understandably, though mistakenly, he wrote that 'human beings and their awkwardnesses have been squeezed out.' ${ }^{14)}$ Yet there is a world of human awkwardnesses in Charles Tomlinson's uneasy pronouns. When Allott added that Tomlinson was 'an aristocratic “mutile" of the aesthetic war' he mistook Tomlinson's 'one' for the thing itself. Tomlinson is not an aristocrat-rather, in 'Tramontana at Lerici' he shows the consequences of a wound inflicted by the feeling that one has to sound like one.

\section{III}

The collection in which 'Tramontana at Lerici' appeared, Seeing is Believing (1960), was widely praised; praise, though, qualified by many with criticism that the book lacked a human dimension, had no people in it. John Rathmell, writing in the magazine Prospect, said:

in the face of the very considerable achievement represented by Seeing is Believing it would be perhaps disingenuous to ask for more than the very great deal he has in fact done; yet in the final analysis one cannot help feeling that the implied defence:

There are portraits and still-lifes

And the first, because 'human'

Does not excel the second... is specious. ${ }^{15)}$

Kenneth Allott confessed: 'I happen to prefer Larkin's "human” poetry, but the quality of the better poems in Seeing is Believing cannot be denied by any honest judge. '16) Fifteen years after the book's appearance, Tom Paulin, commenting on 'Winter Encounters', reiterated the objection:

Though Tomlinson means that there is an energising quality, a sense of true communion and encounter, behind both the people's casual conversation and the 'changing light' and 'responsive stone', the effect is one of detachment and distance-the 'intensity' seems located beyond the human, not within the people who are talking to each other. ${ }^{17}$ 
Whether in response to criticism or not, Tomlinson's next book, A Peopled Landscape seemed designed as an answer to such complaints. One of its poems is just such a peopled landscape drawn from the hillsides above Lerici. 'Up at La Serra' has been described by Vittorio Sereni in a festshrift to celebrate Tomlinson's fiftieth birthday as 'insieme una situazione poetica e un piccolo studio sociologico'18) [at once a poetic situation and a small sociological study]. This poem was composed with the aid of overlayered acts of translation. A problem to explore in it is succinctly stated by Michael Schmidt when he says of the entire volume: 'First, Tomlinson's critics said he was cold because there were not any people in his poems. When he published $A$ Peopled Landscape they were not satisfied. His people joined the rocks and stones and trees on an equal footing, as objects.' ${ }^{19)}$

In the year that Tomlinson published A Peopled Landscape, Oxford University Press issued his translations of the Spanish poet Antonio Machado, Castilian Ilexes: Versions from Machado, which he had made in collaboration with his colleague at Bristol University, Henry Gifford. The word 'Versions' in their title is a signal, for, even at first glance many of the poems look more like works by Tomlinson than Machado. They are written in the 'three-ply', stepped-down line which Tomlinson had adapted for his purposes from William Carlos Williams's later works. One of these, a version of 'Poema de un día' [Poem of a Day], prefigures 'Up at La Serra', and is indicated as a source in Tomlinson's poem:

This was the Day

which began all reckonings

she heard them say

with a woman's ears;

she liked

the music from the wireless.

The padre

pulled

at his unheeded angelus

and the Day went down behind

the town in the bay below [...] 
The capital letter for 'Day' in the two cases it occurs seems a discreet acknowledgement of a debt to 'Poem of a Day'. The 'Poema de un dia', subtitled 'meditationes rurales' [rural meditations], is a monologue spoken by the poet from his isolation at Baeza in 1913, where he taught French in a country school. He situates himself in this obscure province, and this mundane job at the beginning of the poem:

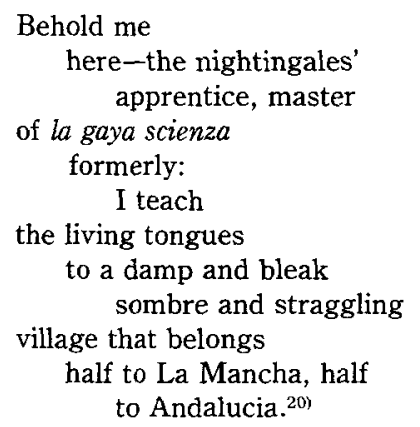

Machado moved to Baeza from Soria in Old Castille after his wife, to whom he had only been married for a few years, died. This event comes into the first of three passages I want to look at with an eye on the Spanish. It is a language which I can make out with a dictionary open, and my remarks are no more than interested suggestions:

En estos pueblos, ¿se escucha

el latir del tiempo? No.

En estos pueblos se lucha

sin tregua con el reló, con esa monotonía que mide un tiempo vacio.

Pero ¿tu hora es la mía?

¿Tu tiempo, reloj, el mío?

(Tic-tic, tic-tic...) Era un dia

(Tic-tic, tic-tic) que pasó,

y lo que yo más quería

la muerte se lo llevó. ${ }^{21)}$

Here is Tomlinson: 
in villages like these

does one catch

the pulse of time?

Truceless

before the clock

one, rather, fights

against monotony

alights

that, in these villages

to measure

the passage of their vacancies.

But, clock, is yours

this time of mine-

are mine your hours?

(Tick, tick)

There was a day

(tick, tick) that passed

and that which I

most loved

death made away. ${ }^{221}$

The rhythms and lineations of Tomlinson's version keep a reader's attention focussed, at the price of a preciosity in the isolation and placing of words: the technical self-consciousness of 'alights/ to measure/ the passage [...]' in comparison with Machado's one line 'que mide un tiempo vacio', or Tomlinson's commitment to the 'three-ply' line dismembering Machado's two plain lines of lament ('y lo que yo más quería/ la muerte se lo llevó'), adding a touch of melodrama or sentimentality with the catch in the breath where the line breaks on the first person singular: 'and that which $\mathrm{I} /$ most loved/ death made away.' A related nicety, this time tonal, may be noted in the treatment of a shift in the passage from impersonal questioning to Machado's own predicament. Tomlinson's use of the pronoun 'one' with third person singular verbs imitates this change from 'se escucha' and 'se lucha' to 'tu hora es la mia'; yet, again, there seems a class tone and detachment which sits uneasily with the opening of Tomlinson's translation, or of the original: not least because the tone is distinctly English, and its engrafting onto a Spanish location appears askew. With the 'rather' in 'one, rather, fights/ against monotony', the word is sanctioned by the 
'No' in Machado's text; yet the character of these turns in the meditation is different. The Spanish seems a confrontation with a flat contradiction:

In these villages, do you hear the beat of time? No.

In these villages you struggle Without let-up with the clock With this monotony...

Tomlinson's 'one, rather, fights/ against monotony' articulates a moral preference. It resembles this clause from the long last sentence of Chapter I, The Stones of Venice: 'or whether, rather, we shall not behold in the brightness of her accumulated marble pages on which the sentence of her luxury was to be written'. ${ }^{23)}$ Tomlinson's tonal engrafting momentarily lifts the speaker from his constricting context and lets him contemplate as an alternative what appears to be a necessity.

How is the speaking self situated within and with regard to its own experience? There are passing verbal echoes of Tomlinson's translation in other poems from A Peopled Landscape. In 'The Picture of J. T. in a Prospect of Stone' an internal dialogue includes: 'Say, rather/ it resists' (74); while in 'John Maydew or The Allotment' the figure delineated is last seen eyeing a toad which breathes 'in the assuagement/ of his truce' (67)-a compromise with post-war English history, fixed by Tomlinson in a word that may derive from the 'tregua' of Machado's poem. These instances catch a dilemma in Tomlinson's outlook, for John Maydew is caught good and proper by his situation, and this 'truce' is part of his entrapment, while the 'rather' in 'The Picture of J. T. ...' is mental play, conjuring possibilities with which to meditate on a glimpse of the poet's own daughter. The thinking and speaking self is situated outside the context in which the object of its meditation lives. This gain in freedom from the entrapping location incurs a loss of purchase. The mind and the speaking self in Tomlinson's poems frequently display a disembodiment, and this is not what appears in the conclusion to 'Poema de un dia': 
Sobre mi mesa Los datos

de la conciencia, immediatos.

No está mal

este yo fundamental,

contingente y libre, a ratos,

creativo, original;

este yo que vive y siente

dentro la carne mortal

iay! por saltar impaciente

las bardas de su corral. ${ }^{24)}$

Here's how Tomlinson renders the poem's end:

My table bears

immédiates.

les données de la conscience

It's adequate

this I

that's fundamental

and at times

creative and original, that

mingling in mortality

its freedom and contingency,

can feel

can see, and yet

must overleap the confines

of its narrow keep. ${ }^{25)}$

Tomlinson's version earns respect and admiration for its fluid rhyming of conceptually weighty but relatively textureless abstractions. He has created his own technical problem in part, though, and found an impressive solution. The Spanish appears nearer to embodied existence. Machado's 'yo' is not 'mingling in mortality', like an individual in a crowd, but 'dentro la carne mortal' [within mortal flesh]. Also, it does not mingle 'its freedom and contingency', like possessed qualities, but is contingent and free.

The difference is, on the one hand, between the statement of my being subject to conditions of time and space, being an organic entity inseparable from its position on the earth, and from which position I gain some conceptual independence through speaking and writing; and, on the other, seeming to 
acknowledge that I, the speaking voice of the poem, do derive from a body that has contingency and mortality, though what a reader mainly experiences is my freedom, my ability to 'overleap the confines' of my circumstances. It's as if the voice of the Tomlinson translation faintly condescends to its own body, and to the pronoun with which it identifies itself as the subject of sentences. This is the difference between saying in two lines 'No está mal/ este yo fundamental' and saying in three 'It's adequate/ this I/ that's fundamental'. Similarly, different senses of embodiment appear in the grammars of the final lines. In Machado's poem the 'yo' 'vive y siente [...] por saltar impaciente' [lives and feels...to overleap, impatient]. In the Tomlinson it is not incorporated so as to grow larger than its confines, but is required to turn against its physical limits in order to fulfil the obligation to be impersonal, not restricted to its own small sphere. The 'I' 'can feel/ can see, and yet/must overleap'. Tomlinson's 'and yet' interprets Machado's 'iay!': an ambiguous exclamation becomes a measured explanation. The English version dramatises a self which is socially and morally, in diction and syntax, armoured against the material limits of its own body.

\section{IV}

The relevance of Machado's 'Poema de un dia' to 'Up at La Serra' is that both poems have in them poets living in obscure provincial villages who are attempting to give themselves the confidence to make significant art of their restricted circumstances, or, in Machado's case, achieving it by asking if it can be done. The poet in 'Up at La Serra' is Paolo Bertolani, and La Serra is his village, on the hillside above Lerici. He was born there in 1931, was twenty years old when Tomlinson met him first, and situated him in his own peopled landscape. Before looking in detail at what 'Up at La Serra' achieves and the problem it contains, I should quote Tomlinson's own trepidations, on discovering, twenty years later, that the person he had put in his poem had continued to write poetry and fiction. In Some Americans, Paolo Bertolani- 
discovered from Vittorio Sereni, who coincidentally owned a holiday house nearby, that I had long ago written a poem called 'Up at La Serra.' This work was something of an embarrassment to me, for in it I had tried to imagine the life of a young poet "up at La Serra" who

knew, at twenty

all the deprivations such a place

stored for the man

who had no more to offer

than a sheaf of verse

in the style of Quasimodo....

I wrote the poem at a time when I was experimenting in the use of Williams's three-ply cadences. It was the first of a series in which people are trapped by political or historic situations. Without La Serra-and without Williams-I might not have got these poems under way, so once more Italy and America had combined for me. By the seventies, however, and by the time I resumed contact with Paolo, I came to wonder whether I had not been tactless in using names-his name in particular-and presumptuous, even, in venturing to imagine what had been in his mind in the $1950 \mathrm{~s} .{ }^{26)}$

I like Tomlinson's readiness to acknowledge debts incurred. Just as Williams helped him with his own poems, so also with Machado's poem. He translates Machado into a form translated from America, in order to translate into English poetry the experience of a small village in Italy, and this helped him write about the English provinces in poems such as 'John Maydew or The Allotment'. The possibilities for disorientation and mis-matching are extreme, and it is largely a measure of Tomlinson's skill that objection or offence from those involved was not taken. Sereni translated the poem into Italian to read at a launch for Bertolani's second book Incertezza dei bersagli at Vicenza in 1976. Following the passage Tomlinson cites above, 'a sheaf of verse/ in the style of Quasimodo', these lines appear:

Came the moment,

he would tell it

in a poem

without rancour, a lucid

testament above his name

Paolo

Bertolani 
-Ciao, Paolo!

- Ciao

Giorgino!

He would put them

all in it $-[\ldots]$

Tomlinson has done just this: he has put them all in. Yet what âtout himself? The difference between 'Up at La Serra' and 'Poema de un dia' is that in the latter Machado is present and speaking. He is experiencing and conveying the feeling of being trapped by political and historic situations. Tomlinson presents dialogue between Bertolani and others, including tourists, foreigners such as the poet will have appeared:

the visitors:

and you told

We are not communists

although we call ourselves communists

we are what you English

would call...socialists.

Is this being said to the poet Charles Tomlinson? It sounds as if he had translated it from Bertolani's Italian, remembered or imagined. Yet 'Up at La Serra' doesn't at any point contain the poet as a physical entity in the imagined space of the poem, receiving the experience he relates to readers. An election is taking place, and, in the evening, news arrives of the results:

the election.

-We have won

-At the café

the red flag is up.

He turned back

quickly beneath the tower.

Giorgino

who wanted to be a waiter

wanted to be a commissar

piling sassi

into the dentist's wall. 
The word 'sassi' means 'stones' or 'pebbles'; it stands out from the passage not only because a foreign language, but because it follows a group of lines which might have sounded something like: "Habbiamo vinto l' elezione. La bandiera rossa è lassú al bar!" If this snatch of conversation has made it into English italics, why has the Italian word for stones been left in the original? This is a mark, among many others, of the poet's presence writing the poem. Yet, unlike the indications that derive from the practically innumerable instances of conscious technique which could be pointed to, the presence of the Italian word does not indicate the poet absorbed into the form of his words, but to the presence of an Englishman abroad.

Tomlinson's final chapter in Some Americans is sprinkled with short phrases in Italian and italics. There is 'the old, luxuriantly white-moustached peasant who offered a whole history of the modern world through his account of the growth and decline of $i$ baffi, the moustache'27) and the man who 'never married and, having bought the land that had belonged to a local count, was known for the rest of his life as il conte', and there are 'those who in tempo di guerra had hidden in holes in the ground to avoid the conscription'; these people 'like Paolo, were faced with the prospect of unemployment and looked to the communists-they had just won the elections hereabouts-to put things to rights.' Tomlinson's tone here is nostalgic and affectionate. It too has wanted to, and has put things to rights.

By comparison, 'Up at Serra' treats the situation with a faintly knowing, possibly helpless condescension. Here is a passage about Bertolani at twenty, and what he, perhaps, had said to Tomlinson of his hopes-

He believed

that God was a hypothesis,

that the party would bring in

a synthesis, that he

would edit the local paper for them,

or perhaps

go northward to Milan [...] 
By saying, 'He believed', the English poet distances his own voice from the hopes or fears that his Italian confrere experiences, mediating them to the England of the Conservative Prime Minister, Harold Macmillan and his slogan 'You've never had it so good'. Tomlinson's use of occasionally dropped Italian substantives like 'sassi' or 'baffi' gives his writing set in foreign places a smack of the local tongue, as any good travel writer might. Yet that is exactly the moment when the poet situates his voice outside the concerns that he reports. This may be thought honest of him, and more judicious than Ezra Pound's attempt to read everywhere as instancing his polemical vision. Tomlinson's detachment nevertheless implies an authority which derives from not being situated and defined in a relation to the occasion composed. The poet's line-endings in 'He believed/ that God was a hypothesis/ that the party would bring in/ a synthesis' sceptically weigh the Italian's hopes, pausing before what he believes in each case. The effect is similar to a crafty sentence of James Joyce's from 'Eveline'. Frank, Eveline's sailor sweetheart is telling her about the life he will take her away to: 'He had fallen on his feet in Buenos Ayres, he said, and had come over to the old country just for a holiday. ${ }^{28)}$ Joyce's "he said' is designed to prompt doubts about what Frank is saying; Tomlinson is not deliberately doing the same with the 'He believed', but it serves to make English readers doubt the acuity of young Italians believing in the PCI, the Italian Communist Party.

There is also talk of elections in Machado's 'Poema de un dia':

Es de noche. Se platica

al fondo de una botica.

-Yo no sé,

don José,

cómo son los liberales

tan perros, tan inmorales.

- OOh, tranquilícese usté!

Pasados los carnavales, vendran los conservadores, buenos administradores de su casa. ${ }^{29)}$ 
Tomlinson paraphrases this in his version:

Night:

the talk is on

in the rear room

at the apothecary's

where they define

what makes the liberals such swine

and Don José

scents consolation

in the return (predicted)

of the conservative administration $[\ldots]^{30)}$

A detail the translation doesn't contain is the local landowner's being sucked up to by the other voice speaking at the apothecary's: 'Yo no sé,/ don José'. And this allows Don José to respond with home-grown political wisdom about the party of his own interests. Machado is outside the village shop where such talk goes on, both in that he is not taking part, and that the opinions expressed are not his own, so that he feels himself, as poet and citizen, removed from the locals' outlook. However, his exclusion is a form of belonging. It is part of his situation, like the expression of support for Italian communist intellectuals in Sereni's 'Un posto di vacanza', set, a few miles down the coast from La Serra, at Bocca di Magra, and in the year Tomlinson first visited Liguria:

e nel '51 la lagna di un raro fuoribordo su per il fiume

era ancora sottilmente allarmante, qualunque cosa andasse sul filo della corrente passava per testa mozza di trucidato.

Ancora balordo di guerra, di quella guerra solo questo mi univa a quei parlanti parlanti e ancora parlanti sull'onda della libertà...31)

[and in '51 a rare outboard motor's whine up river/ was insidiously alarming still,/ whatever was floating on the line of the current/ passed for a slaughtered man's lopped head./ Stunned by war still, by that war,/ only this united me with those speakers speaking/ and still speaking on the wave of liberty...]. It is Sereni's sense of being cauterized by the war, of sharing a historic fate, even in the division and exclusion of his imprisonment in North Africa during 1943-5, 
which unites him with the theoreticians of liberty whom he brushes against on holiday. Such a lack of attachment, such exclusion or equivocation, these form part of the writer's situation within the world experienced and mediated. Tomlinson's pasition on the fringes of ' $\mathrm{Up}$ at La Serra' is more marginal-but by excluding himself from the picture he risks being tactless by not seeming to have experienced the facts, the situation, in which he places his protagonists, nor even to have experienced his own irrelevance.

In the published letter to Tomlinson, Sereni concluded with these generous words:

Ebbene, caro Tomlinson, la spregiudicatezza nel vedere e nell'ascoltare con cui la sua poesia affronta le cose conferma questa qualità per cui la poesia è davvero un mezzo di conoscenza. Ma in lei tale qualità è doppiata e rafforzata da questa caratteristica: non c'è in lei (per questo parlavo di spregiudicatezza) alcuna conoscenza precostuita. In lei la conocenza è un risultato, un coronamento dell' esperimento specifico, si forma col formarsi della poesia. Questa lezione è per noi importante, mi induce ad avvertire una affinità con lei e col suo lavoro, accende fiducia in me verso me stesso. ${ }^{32)}$

[Well, dear Tomlinson, the lack of prejudgement in seeing and hearing with which your poetry confronts things confirms this quality by which poetry is truly a means for understanding. But in you, such quality is doubled and reinforced by this characteristic: in you there is not (it's why I mentioned lack of prejudgement) any preconstituted understanding. In you understanding is an outcome, a crowning of the specific experiment, it forms with the formation of the poem. This lesson is important for us, induces me to notice an affinity with you and your work, it kindles fidelity in me towards myself.] The openmindedness with which the poet, in Sereni's formulation, sees and hears is a quality to which Tomlinson has committed himself, and it is a means for understanding the world. Reservations about the extent to which Tomlinson has conducted specific experiments in perception free from preconceived understandings, are prompted by a sense that an 'I' is withheld, but a detached source of knowledge and judgement implied. This is why Tomlinson was afraid that 'Up at La Serra' might appear tactless and presumptuous. 
The gift of an affinity with Tomlinson in Sereni's letter involves his including himself within the process of understanding that the Italian poet sees as a prerequisite of poetic knowledge. When he says that Tomlinson's work 'accende fiducia in me verso me stesso', he finds in his response to it a quality different to the sense in 'Tramontana at Lerici' that the pronoun 'One' in 'One is ignored' turns the poet away at the door of his own self. Sereni discovers, in reading Tomlinson's poems, that his own self, as a contingent and free locus of poetic perception, is reinvigorated. 'Up at La Serra' concludes with the twenty-year-old Italian poet's confidence in his powers:

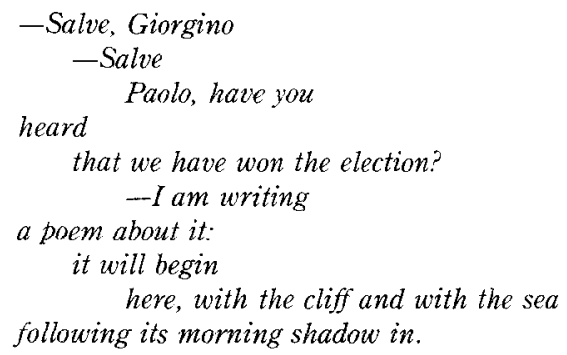

Since the poem Bertolani is writing will begin at the point where ' $\mathrm{Up}$ at $\mathrm{La}$ Serra' does in fact start- 'The shadow/ ran before it lengthening' (78)-it is as if Tomlinson's poem is a translation in imagination, a shadowing in another language, of the poem Bertolani might have written.

Two poems form afterwords to 'Up at La Serra'. The first, from Bertolani's Incertezza dei bersagli, is called 'La Casa di Charles'. It concludes:

\footnotetext{
Non tornare, se tornare non puoi sopra un uccello marino $e$ in un punto da cui-anche volendotu non possa vedere lo scempio che hanno fatto uomini e anni su quel gioco che era la vita. ${ }^{33)}$
}

['If you return do not/ return unless riding astride/ a seabird's back from the same spot/ where even in flight the eye/can't seize on this scape that men/ and 
the years have unshaped from the play that was life. ${ }^{34)}$ ] The thought of a seabird's flying is picked up in 'Graziella', the third part of 'The Return', the title poem (dedicated to Paolo Bertolani) of Tomlinson's 1987 collection. Graziella was the Italian poet's wife, who had died after a painful illness:

The dead do not return, and nor shall we

To pry and prompt the living or rehearse

The luxuries of self-debating verse.

Their silence we inhabit now they've gone

And like a garment drawn the darkness on

Beyond all hurt. This quiet we must bear:

Put words into their mouths, you fail to hear

What once they said. I can recall the day

She imitated my clipped, foreign way

Of saying Shakespeare: English, long unheard,

Came flying back, some unfamiliar bird

Cutting a wing-gust through the weight of air

As she repeated it -Shakespeare Shakespeare-

Voice-prints of a season that belongs

To the cicadas and the heat, their song

Shrill, simmering and continuous. ${ }^{35)}$

Charles Tomlinson's work between 1951 and 1963 has an instructive uneasiness in the poet's articulation of his self and his 'I'. Antonio Machado was justified in taking strength from his contingent 'yo': 'No está mal/ este yo fundamental,/ contingente y libre'. It is a necessary locus of poetic knowledge, heard in the reciprocity of Bertolani's and Tomlinson's poems, the echoing of 'Non tornare' in 'do not return' and the 'uccello marino' in 'some unfamiliar bird'. 'I can recall the day', Tomlinson writes, the locus of a poetic knowledge, a place in the world, an 'I' revitalised for Vittorio Sereni by some of the English poet's earlier work, helping him kindle a "fidelity in me towards myself." 


\section{Notes}

1) See D. H. Lawrence, The Complete Poems ed. de Sola Pinto and Warren Roberts (Harmondsworth, 1977) p. 9.

2) Guido Cavalcanti, Rime ed. Cattaneo (Turin, 1967) p. 61.

3) T. S. Eliot, Collected Poems 1909-1962 (London, 1963) p. 95.

4) See Charles Tomlinson, Collected Poems (Oxford, 1985) p. 26-7, and for his 'Fiascherino', pp. 12-3. Page numbers in parentheses refer to this volume.

5) Charles Tomlinson, Some Americans: A Personal Record (Berkeley and Los Angeles, Cal., 1981) p. 98.

6) 'Charles Tomlinson at Sixty: in conversation with Richard Swigg' in PN Review 59, vol. 14 no. 3, 1987, p. 58. However, in 'The Unison: A Retrospect' from Renga: A chain of poems by Octavio Paz, Jacques Roubaud, Edoardo Sanguinetti, and Charles Tomlinson (Harmondsworth, 1979) p. 37, Tomlinson observes of himself that 'one belonged, oneself, to a country where, at school, children are taught, in their writings (or were up to a generation ago), "Never say I!"

7) Some Americans p. 125.

8) Donald Davie, Collected Poems 1950-1970 (London, 1972) p. 136.

9) Charles Tomlinson, Poetry and Metamorphosis (Cambridge, 1983) p. 3.

10) Ibid., p. 5

11) Ibid., p. 26

12) T. S. Eliot, Collected Poems 1909-1962 p. 209.

13) Michael Schmidt, 'Charles Tomlinson' in PN Review 52, vol. 13 no. 2, 1986, p. 71.

14) This and the following citation, Kenneth Allott, The Penguin Book of Contemporary Verse, second edn. (Harmondsworth, 1962) p. 363.

15) John Rathmell, 'Charles Tomlinson' in Prospect, winter 1960, p. 38.

16) Allott, p. 362.

17) Tom Paulin, Thomas Hardy: The Poetry of Perception (London, 1975) p. 9.

18) 'A Letter from Vittorio Sereni', in PN Review 5, vol. 5. no. 1, 1977, p. 42.

19) Schmidt, op. cit., p. 71.

20) Charles Tomlinson, Translations (Oxford, 1983) p. 34.

21) Antonio Machado, Poesias completas, tenth edn. (Madrid, 1984) pp. 204-5.

22) Translations p. 36.

23) John Ruskin, Works ed. Cook and Wedderburn, Library Edition, 39 vols. (London, 1903-12) 9, p. 59. Tomlinson acknowledged a debt to Ruskin in Peter Orr, The Poet Speaks (London, 1966) p. 250 and see, for examples, Collected Poems pp. 35 and 101-2.

24) Poesias completas, p. 208.

25) Translations pp. 41-2.

26) Some Americans pp. 120-1.

27) This and three following citations, Some Americans p. 108.

28) James Joyce, Dubliners (Harmondsworth, 1956) p. 37. 
29) Poesías completas p. 207.

30) Translations p. 40.

31) Vittorio Sereni, Tutte le poesie ed. Maria Teresa Sereni (Milan, 1986) p. 239. 'Un posto di vacanza' was first published in its entirety in Almanacco dello Specchio 1, 1972 , pp. 105-12, in an issue which included twenty-one poems by Charles Tomlinson and a selection of Paolo Bertolani's work.

32) Sereni, op. cit.

33) Paolo Bertolani, Incertezza dei bersagli (Milan, 1976) pp. 35-6.

34) Some Americans p. 122.

35) Charles Tomlinson, The Return (Oxford, 1987) p. 10. 